EXTENDED REPORT

\title{
Interferon $\beta$ stimulates interleukin 1 receptor antagonist production in human articular chondrocytes and synovial fibroblasts
}

\author{
G Palmer, F Mezin, C E Juge-Aubry, C Plater-Zyberk, C Gabay, P-A Guerne
}

Ann Rheum Dis 2004;63:43-49. doi: 10.1136/ard.2002.005546

See end of article for authors' affiliations

Correspondence to:

Dr P-A Guerne, Division of Rheumatology, University

Hospital, 26 avenue de

Beau-Sejour 1211 Geneva

14 , Switzerland;

Pierre-Andre Guerne@

medecine.unige.ch

Accepted 28 April 2003
Background: Interferon (IFN) $\beta$ displays anti-inflammatory and immunosuppressive activity and has been considered for the treatment of rheumatoid arthritis (RA). Information about the effects of this molecule on joint cells is scarce, however.

Objective: To investigate the effects of IFN $\beta$ on the production of interleukin-1 receptor antagonist (IL1Ra) in human articular chondrocytes and synovial fibroblasts.

Methods: Chondrocytes and synovial fibroblasts were stimulated with IFN $\beta$ alone or in combination with interleukin (IL) 1 $\beta$. IL1Ra concentrations in culture supernatants and cell lysates were determined by ELISA. Expression of mRNA encoding the secreted sIL1Ra or the intracellular iclL1Ral isoforms was quantified by real time reverse transcriptase-polymerase chain reaction.

Results: In chondrocytes, IFN $\beta$ alone had no effect, but dose dependently enhanced the secretion of IL1Ra induced by IL1 $\beta$. Chondrocyte cell lysates contained undetectable or low levels of IL1Ra, even after stimulation with ILI $\beta$ and IFN $\beta$. Consistently, ILI $\beta$ and IFN $\beta$ induced sIL1Ra mRNA expression in chondrocytes, while expression of iclL1Ral was not detectable. Human articular chondrocytes thus mainly produce secreted IL1Ra. In synovial fibroblasts, IFN $\beta$ alone dose dependently increased ILI Ra secretion. In addition, IFN $\beta$ enhanced the stimulatory effect of ILI $\beta$ on ILIRa production. In synovial cell lysates, IFN $\beta$ and IL1 $\beta$ also increased IL1Ra levels. Consistently, IFN $\beta$ and ILI $\beta$ induced the expression of both sIL1Ra and iclL1Ral mRNA in synovial fibroblasts.

Conclusion: IFN $\beta$ increases IL1 Ra production in joint cells, which may be beneficial in cartilage damaging diseases such as RA or osteoarthritis.

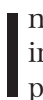
nterferon (IFN) $\quad \beta$ displays anti-inflammatory and immunosuppressive activity, and IFN $\beta$ is emerging as a potentially effective form of treatment in immune mediated conditions such as multiple sclerosis. IFN $\beta$ also demonstrated effects in animal models of arthritis, as well as in human rheumatoid arthritis (RA). ${ }^{1}$ However, little information is available about the effects of IFN $\beta$ on joint cells. Anti-inflammatory effects triggered by IFN $\beta$ include decreased expression of proinflammatory cytokines, such as interleukin (IL) 1 and tumour necrosis factor $\alpha$, and increased expression of anti-inflammatory cytokines, such as IL10 and ILl receptor antagonist (ILIRa). ${ }^{1}$ Such effects, by being chondroprotective, might also prove beneficial in osteoarthritis (OA).

The precise cause of OA is still incompletely resolved, but evidence suggests that an imbalance between catabolic cytokines and protective factors plays a part in cartilage alteration. ${ }^{23}$ In this regard, ILl and its natural inhibitor ILIRa seem to have an important role. These cytokines are indeed present in the synovial fluid and therapeutic interventions aimed at correcting the ILI/ILIRa dysbalance proved effective in animal models of OA..$^{2-4}$

ILlRa is a member of the ILl family that binds to ILl receptors but does not induce any intracellular response. ILlRa prevents the interaction between ILl and its cell surface receptors and thus, competitively inhibits its biological effects. ${ }^{5-7}$ IL1Ra is produced as four different isoforms, one secreted (sILIRa) and three intracellular (icILIRal, 2, 3), derived from the same gene. ${ }^{7}$ The sILIRa and icILIRal mRNAs are transcribed from different promoters and contain isoform-specific $5^{\prime}$ sequences owing to alternative splicing. ${ }^{8}$ The mRNA for icILlRa2 is transcribed from the icILlRal promoter, but contains an additional exon. ${ }^{10}$ Finally, icIL1Ra3 is produced by alternative translation initiation from the sIL1Ra transcript. ${ }^{11}$ Expression of the various IL1Ra isoforms is cell type and stimulus-specific ( see review by Arend $e t \mathrm{al}^{7}$ ).

IFN $\beta$ has been reported to increase ILIRa production in various cell types. ${ }^{12-14}$ However, the effects of IFN $\beta$ on the production of this anti-inflammatory cytokine have not been investigated in joint cells. Biological effects of IFN $\beta$ were previously reported in a human chondrosarcoma derived cell line, as well as in human fibroblast-like synoviocytes, indicating that both chondrocytic cells and synovial fibroblasts might respond to IFN $\beta{ }^{15}{ }^{16}$ Thus this study aimed at examining the potential effects of IFN $\beta$ on ILlRa production in human articular chondrocytes and synovial fibroblasts.

\section{MATERIALS AND METHODS \\ Materials}

Cell culture reagents were obtained from Gibco (Life Technologies AG, Basel, Switzerland). Commercially available IFN $\beta$ la (Rebif; Serono International SA, Geneva, Switzerland; specific activity $250 \times 10^{6} \mathrm{U} / \mathrm{mg}$ ) was used for these studies. Recombinant human ILl $\beta$ was purchased from

\footnotetext{
Abbreviations: AMV-RT, avian myeloblastosis virus-reverse transcriptase; CIA, collagen induced arthritis; ELISA, enzyme linked immunosorbent assay; FCS, fetal calf serum; iclL1Ra, intracellular IL1 receptor antagonist; IFN, interferon; IL, interleukin; IL1Ra, ILI receptor antagonist; LC, Light Cycler; MMP, matrix metalloproteinase; OA, osteoarthritis; PCR, polymerase chain reaction; RA, rheumatoid arthritis; RT-PCR, reverse transcription and polymerase chain reaction; sILIRa, secreted ILI receptor antagonist; TIMP, tissue inhibitor of matrix metalloproteinase
} 
Table 1 PCR primer location and sequence

\begin{tabular}{|c|c|c|c|c|}
\hline Primer & Gene & GenBank & Location (bp) ${ }^{*}$ & Sequence $5^{\prime}-3^{\prime}$ \\
\hline A & IFNARI & NM000629 & $505-524(\mathrm{~s})$ & GTGATACACATCTCTCCTGG \\
\hline B & IFNARI & NM000629 & $830-807$ (as) & GTATAATCCCATTIAAGAACATAG \\
\hline C & IFNAR2 & NM000874 & $545-566(\mathrm{~s})$ & GAGTAAACCAGAAGATITGAAG \\
\hline $\mathrm{D}$ & IFNAR2 & NM000874 & $938-918$ (as) & CGTGTITGGAATTAACTTGTC \\
\hline $\mathrm{E}$ & ILIRN & U65590 & $16128-16147(\mathrm{~s})$ & TTATGGGCAGCAGCTCAGTT \\
\hline $\mathrm{F}$ & ILIRN & U65590 & $25831-25851(\mathrm{~s})$ & TCCGCAGTCACCTAATCACTC \\
\hline G & ILIRN & U65590 & $29134-29115$ (as) & TTGACACAGGACAGGCACAT \\
\hline $\mathrm{H}$ & $28 S$ & U13369 & $10661-10679$ (s) & TTGAAAATCCGCGGGAGA \\
\hline I & $28 S$ & U13369 & $10760-10741$ (as) & ACATTGTTCCAACATGCCAG \\
\hline
\end{tabular}

* Sense (s) or antisense (as) orientation with respect to the corresponding gene is indicated.

Table 2 PCR primer combinations and conditions

\begin{tabular}{lllll}
\hline CDNA & $\begin{array}{l}\text { Forward } \\
\text { primer }\end{array}$ & $\begin{array}{l}\text { Reverse } \\
\text { primer }\end{array}$ & $\begin{array}{l}\text { Annealing } \\
\text { temp. }\left({ }^{\circ} \mathrm{C}\right)\end{array}$ & $\begin{array}{l}\text { Product } \\
\text { length (bp) }\end{array}$ \\
\hline IFNAR1 & $\mathrm{A}$ & $\mathrm{B}$ & 55 & 326 \\
IFNAR2 & $\mathrm{C}$ & $\mathrm{D}$ & 55 & 394 \\
iclL1Ral & $\mathrm{E}$ & $\mathrm{G}$ & 56 & 254 \\
sIL1Ra & $\mathrm{F}$ & $\mathrm{G}$ & 57 & 268 \\
28 S rRNA & $\mathrm{H}$ & $\mathrm{I}$ & 54 & 100 \\
\hline
\end{tabular}

R\&D Systems (Abingdon, United Kingdom). DNAse I, avian myeloblastosis virus-reverse transcriptase (AMV-RT) and random hexamer primers were obtained from Promega (Wallisellen, Switzerland). Light Cycler (LC) polymerase chain reaction (PCR) reagents were purchased from Roche Molecular Biochemicals (Rotkreuz, Switzerland).

\section{Cell isolation and culture}

Cartilage was obtained from patients undergoing joint replacement (knee or hip prosthetic surgery) for OA or broken femoral neck (normal adult cartilage) or from children undergoing spinal surgery for scoliosis (vertebral posterior joints-normal paediatric cartilage). Synovium was obtained from patients undergoing joint replacement (knee or hip prosthetic surgery) for OA or RA. Chondrocytes and synovial fibroblasts were isolated by collagenase digestion as reported previously ${ }^{17}{ }^{18}$ and cultured in Dulbecco's modified Eagle's medium supplemented with L-glutamine, streptomycin, penicillin, and $10 \%$ fetal calf serum (FCS). Primary chondrocytes were used directly after isolation from cartilage. Dedifferentiated chondrocytes were used for the various studies between passages 1 and 6 , and synovial fibroblasts between passages 1 and 14. Cells were plated in 96 well plates for assessment of IL1Ra production (40 000 cells per well) and in $25 \mathrm{~cm}^{2}$ flasks ( $10^{6}$ cells per flask) for RNA extraction. To reduce the non-specific effects of agonists present in FCS, the cells were incubated in low serum $(0.5 \%$ FCS) medium for 24 hours before stimulation with the various agents.

\section{ELISA for human ILIRa}

After incubation of the cells with cytokines for the indicated times, the culture supernatants were collected and stored at $-20^{\circ} \mathrm{C}$. Cell lysates were obtained by adding fresh medium containing 1\% NP-40 to the cells. The concentrations of IL1Ra in supernatants and lysates were measured by a sandwich enzyme linked immunosorbent assay (ELISA), as previously described. ${ }^{19}$ This ELISA detects all ILlRa isoforms. The detection limit of the assay is $78 \mathrm{pg} / \mathrm{ml}$.

\section{RNA isolation, reverse transcription and polymerase chain reaction (RT-PCR) analysis}

Total cellular RNA was extracted using the Tripure reagent (Roche Molecular Biochemicals, Rotkreuz, Switzerland). Total RNA ( $3 \mu \mathrm{g}$ ) was digested with DNAse I and reverse transcribed using AMV-RT and random hexamer primers. For the detection of IFNARl and IFNAR2, PCR amplification (35 cycles) was performed using Taq DNA polymerase (Qiagen, Basel, Switzerland) with indicated primer pairs and conditions (tables 1 and 2). For detection of sILIRa and icILlRal, quantitative real time PCR was performed with an LC (Roche Molecular Biochemicals) using the FastStart DNA Master SYBR Green I reaction mix, appropriate primer pairs, and conditions (tables 1 and 2). Expression of sIL1Ra or icILlRal mRNA was corrected for $28 \mathrm{~S}$ ribosomal RNA (rRNA) levels, which were quantified by LC real time PCR using indicated primers and conditions (tables 1 and 2). The absence of DNA contamination in RNA preparations was tested by including RNA samples which had not been reverse transcribed. Distilled water was used as a negative control for PCR amplification. The identity of the amplified products was confirmed by DNA sequencing.
A
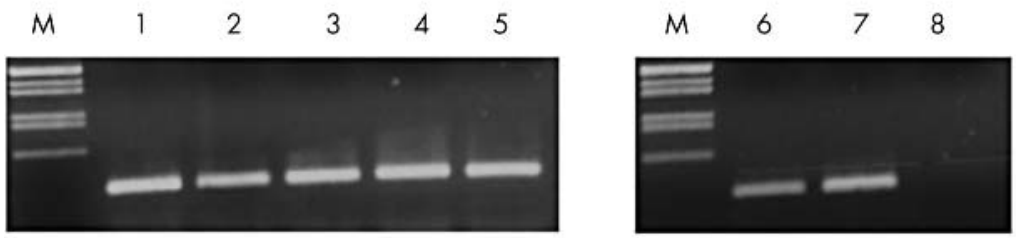

B

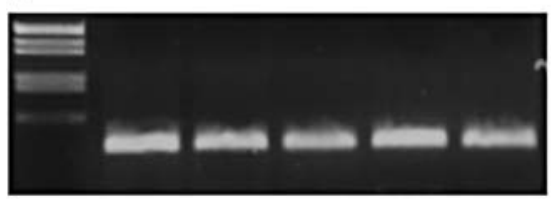

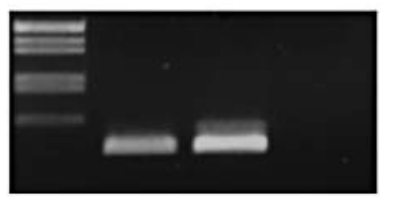

Figure 1 Expression of IFNARI and IFNAR2 mRNA in human articular chondrocytes and synovial fibroblasts. Expression of mRNA encoding (A) IFNAR1 and (B) IFNAR2 was assessed by RT-PCR using total RNA from freshly isolated (lanes 1, 6, 7) or dedifferentiated (passage 1; lanes 4 and 5) human articular chondrocytes or from human synovial fibroblasts (passage 3; lanes 2 and 3). Cells were left unstimulated (lanes $1,2,4,6$ ) or stimulated for 24 hours with $1 \mathrm{ng} / \mathrm{ml}$ IL1 $\beta$ (lanes 3, 5, 7). M: DNA molecular weight marker. Lane 8: distilled water was used as a negative control for PCR - 394 bp amplification. 


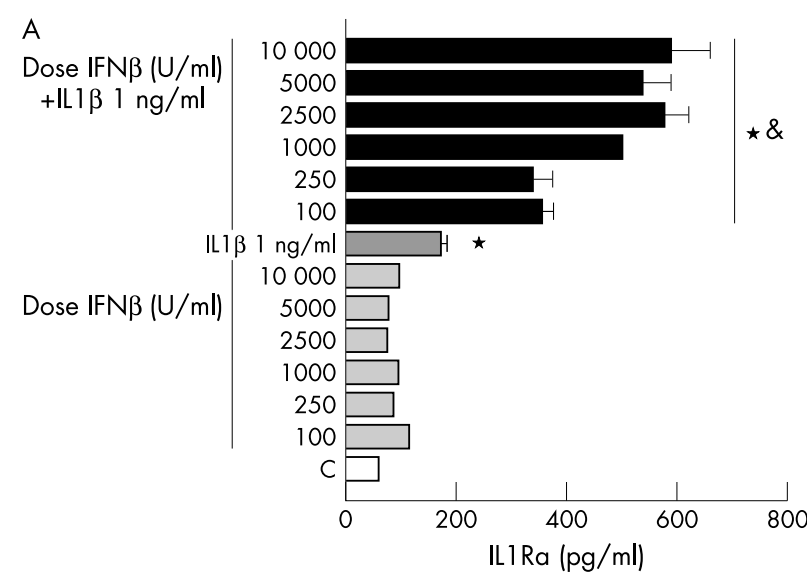

B
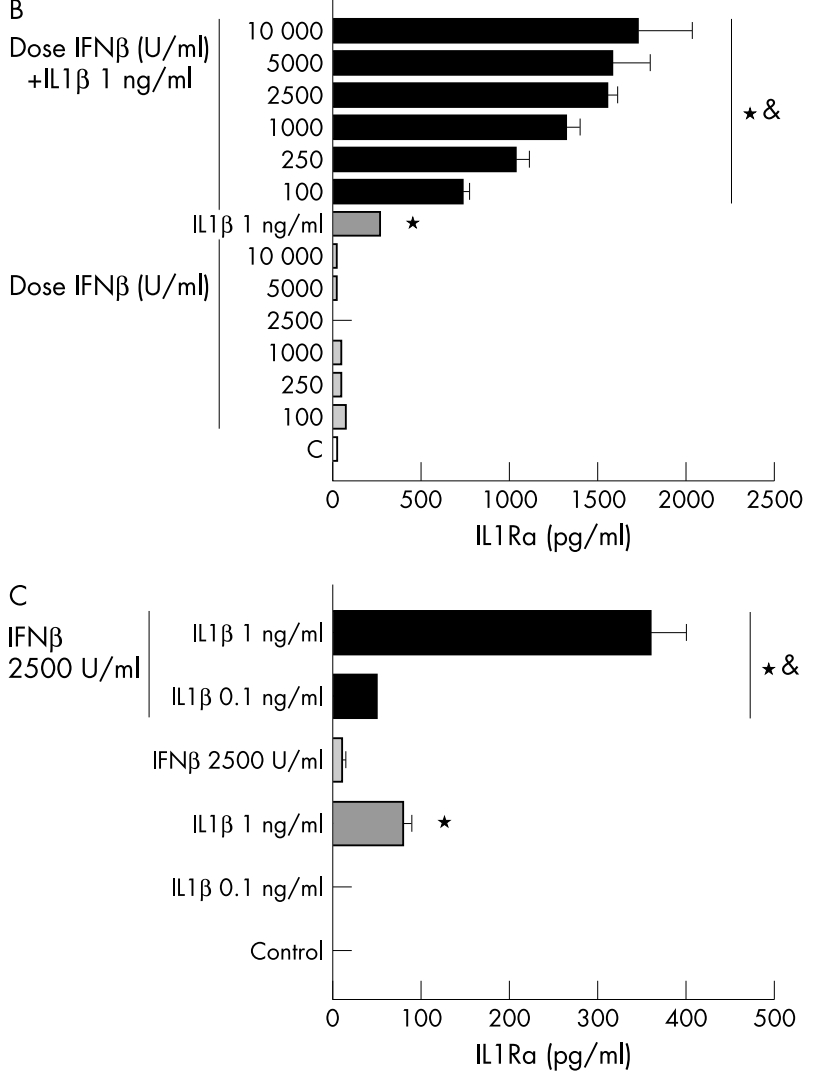

Figure 2 Dose dependent effects of IFN $\beta$ and ILI $\beta$ on ILIRa secretion by human articular chondrocytes. (A) Human articular chondrocytes freshly isolated from OA knee joint cartilage or (B) dedifferentiated human articular chondrocytes (passage 4, OA femoral head) were left unstimulated (control; white bars) or stimulated with indicated doses of IFN $\beta$ (grey bars; $250 \mathrm{U} / \mathrm{ml}$ corresponds to $1 \mathrm{ng} / \mathrm{ml}$ ), $1 \mathrm{ng} / \mathrm{ml} \mathrm{IL1} \beta$ (dark grey bars), or the combination of $1 \mathrm{ng} / \mathrm{ml} \mathrm{ILI} \beta$ and indicated doses of IFN $\beta$ (black bars) for 72 hours. (C) Freshly isolated human articular chondrocytes (OA knee) were left unstimulated (control; white bars) or stimulated with indicated doses of IL1 $\beta$ (dark grey bars), $2500 \mathrm{U} / \mathrm{ml}(10 \mathrm{ng} / \mathrm{ml})$ IFN $\beta$ (grey bar) or the combination of 2500 $\mathrm{U} / \mathrm{ml}(10 \mathrm{ng} / \mathrm{ml}$ ) IFN $\beta$ and indicated doses of IL1 $\beta$ (black bars) for 72 hours. IL 1 Ra concentrations in culture supernatants were measured by ELISA. Each bar represents the mean (SEM) of three determinations in a representative experiment. * $p<0.05$ as compared with control;

$\& p<0.01$ as compared with cells treated with the same dose of ILI $\beta$ alone.

\section{Statistical analysis}

Significance of differences was calculated by analysis of variance. A difference between experimental groups was considered significant for a p value $<0.05$.

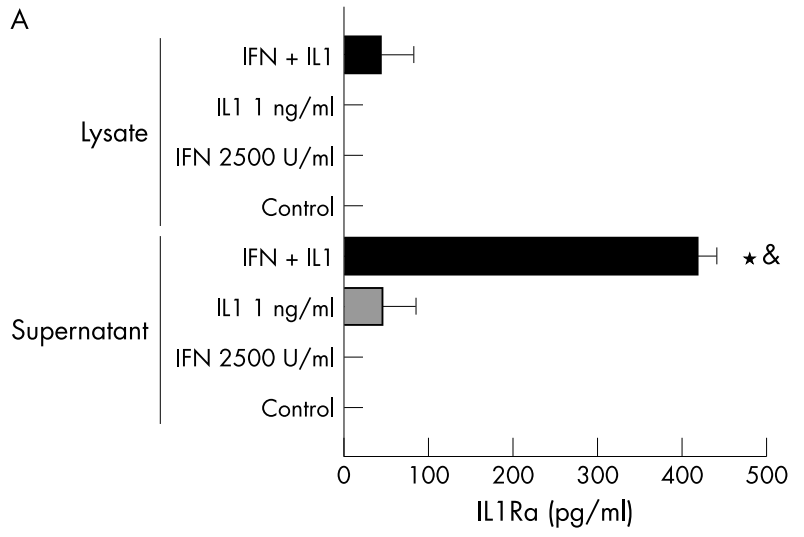

B

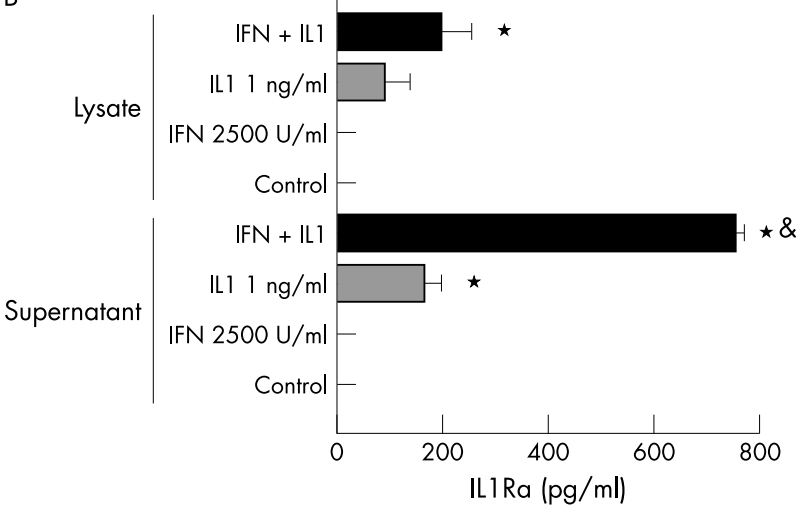

Figure 3 Effects of IFN $\beta$ and ILI $\beta$ on the production of secreted and intracellular IL1Ra by in human articular chondrocytes. (A) Human articular chondrocytes freshly isolated from normal adult femoral head cartilage or (B) dedifferentiated human articular chondrocytes (passage $5, \mathrm{OA}$ femoral head) were left unstimulated (control; white bars) or stimulated with $2500 \mathrm{U} / \mathrm{ml}(10 \mathrm{ng} / \mathrm{ml}$ ) IFN $\beta$ (grey bars), $1 \mathrm{ng} / \mathrm{ml}$ IL1 $\beta$ (dark grey bars), or the combination of $2500 \mathrm{U} / \mathrm{ml}(10 \mathrm{ng} / \mathrm{ml})$ IFN $\beta$ and $1 \mathrm{ng} / \mathrm{ml} \mathrm{IL1} \beta$ (black bars) for 72 hours. IL1Ra concentrations in culture supernatants and cell lysates were measured by ELISA. Each bar represents the mean (SEM) of three determinations in a representative experiment. * $p<0.05$ as compared with control; \& $p<0.001$ as compared with cells treated with IL1 $\beta$ alone.

\section{RESULTS}

Expression of mRNA encoding type I IFN receptors in human joint cells

Type I interferons exert their cellular effects by binding to the IFNARI and IFNAR2 cell surface receptors. ${ }^{20}$ We examined the expression of IFNARI and IFNAR2 mRNA by RT-PCR in human articular chondrocytes and synovial fibroblasts. IFNARI and IFNAR2 transcripts were detected in primary and dedifferentiated chondrocytes, as well as in synovial fibroblasts (fig 1). Furthermore, IFNARl and IFNAR2 expression was seen both in unstimulated cells and after 24 hours' stimulation with $1 \mathrm{ng} / \mathrm{ml} \mathrm{ILl} \beta$. Human joint cells thus produce IFNARI and IFNAR2 transcripts.

\section{Production of IL IRa in response to IFN $\beta$ and ILI $\beta$ in human articular chondrocytes}

We next assessed the effect of IFN $\beta$ on ILIRa production in human articular chondrocytes in the presence or absence of IL1 $\beta$. ILIRa was low in conditioned media of untreated cells, but ILl $\beta$ ( $1 \mathrm{ng} / \mathrm{ml}$ ) stimulated its production (fig 2$)$, as recently described. ${ }^{21}$ IFN $\beta$ had no effect on its own, but dose dependently enhanced the stimulatory effect of ILl $\beta$ on ILIRa production. The effect of IFN $\beta$ on ILl $\beta$ induced ILIRa secretion was maximal at $2500 \mathrm{U} / \mathrm{ml}$ IFN $\beta$ (figs $2 \mathrm{~A}$ and B). A similar dose dependent effect of IFN $\beta$ was seen using cells 
Table 3 ILIRa secretion by OA articular chondrocytes

\begin{tabular}{lll}
\hline Samples & Condition & $\begin{array}{l}\text { ILIRa }(\% \text { of } \\
\text { maximum) }\end{array}$ \\
\hline OA knee $(\mathrm{n}=3)$ & Control & $3.09(3.09)$ \\
Primary cells & IFN $\beta 2500 \mathrm{U} / \mathrm{ml}$ & $4.72(3.64)$ \\
& IL1 $\beta 1 \mathrm{ng} / \mathrm{ml}$ & $18.11(7.71)$ \\
& IFN $\beta$ and IL1 $\beta^{*}$ & $100(0) \ddagger \S$ \\
OA femoral head $(n=5)$ & Control & $1.49(1.24)$ \\
Dedifferentiated cells & IFN $\beta$ & $2.31(2.31)$ \\
& IL1 $\beta$ & $18.77(5.62) \ddagger$ \\
& IFN $\beta$ and IL1 $\beta \dagger$ & $100(0) \ddagger \S$ \\
\hline
\end{tabular}

*ILIRa secretion in primary cells from three different donors, stimulated with $2500 \mathrm{U} / \mathrm{ml}$ IFN $\beta$ and $1 \mathrm{ng} / \mathrm{ml} \mathrm{IL1} \beta$, ranged from 360.1 to $573.1 \mathrm{ng} / \mathrm{ml}$ (mean (SEM) 488.5 (65.3)); +ILIRa secretion in dedifferentiated cells (passages $4-6$, five different donors) stimulated with $2500 \mathrm{U} / \mathrm{ml} \mathrm{IFN} \beta$ and $1 \mathrm{ng} / \mathrm{ml} \mathrm{IL1} \beta$ ranged from 369.2 to $1573.7 \mathrm{ng} / \mathrm{ml}$ (mean (SEM) 771.4 (218.8)); $\ddagger p<0.05 v$ control; $\S p<0.01 v$ IL1 $\beta$ or IFN $\beta$ alone.

from six different donors (two OA knee and four OA femoral head samples). The stimulation of ILIRa production by IL1 $\beta$, used either alone or in combination with IFN $\beta$, was also dose dependent (fig 2C). A similar dose dependent effect of ILI $\beta$ was observed using cells from three different donors (one OA knee and two OA femoral head samples). The response to ILl $\beta$ and IFN $\beta$ was similar in freshly isolated chondrocytes (fig 2A, table 3 ) or in subcultured dedifferentiated cells after 1-6 passages (fig 2B, table 3). Furthermore, similar induction of ILlRa secretion was seen using OA chondrocytes from femoral head or knee, normal adult femoral head chondrocytes, or normal paediatric samples (table 3, figs 2 and 3, and data not shown). Finally, IFN $\beta$ and ILl $\beta$ also increased IL1Ra production in culture supernatants of cartilage explants (OA and normal adult femoral head, data not shown), indicating that this response is not affected by the procedure that we routinely use for chondrocyte isolation.

The effects of IFN $\beta$ and ILI $\beta$ on ILIRa production were time dependent and maximal after 48-72 hours of stimulation (data not shown). Furthermore, the combined effects of IFN $\beta$ and ILl $\beta$ were optimal when both cytokines were added simultaneously; preincubation with IFN $\beta$ did not further enhance the response (data not shown).

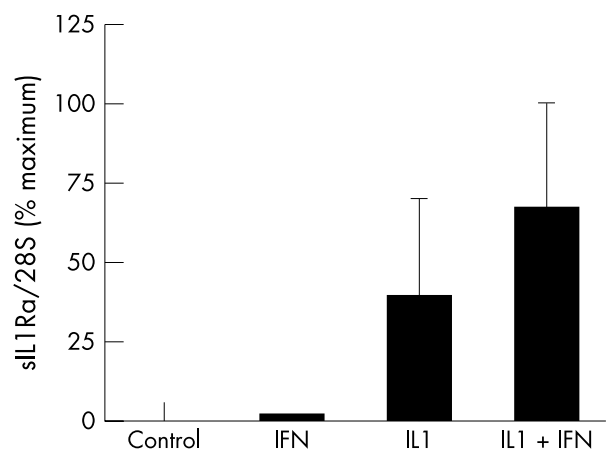

Figure 4 Effects of IFN $\beta$ and ILI $\beta$ on the expression of sILIRa mRNA in human articular chondrocytes. Expression of mRNA encoding sIL1Ra was quantified by real time RT-PCR using total RNA from dedifferentiated human articular chondrocytes (passages 1-3). Cells were left unstimulated (control) or stimulated for 18 hours with 2500 $\mathrm{U} / \mathrm{ml}(10 \mathrm{ng} / \mathrm{ml}$ ) IFN $\beta$ (IFN), $1 \mathrm{ng} / \mathrm{ml}$ ILI $\beta$ (ILI) or the combination of $2500 \mathrm{U} / \mathrm{ml}(10 \mathrm{ng} / \mathrm{ml})$ IFN $\beta$ and $1 \mathrm{ng} / \mathrm{ml}$ ILI $\beta$ (ILI + IFN). The amount of 28S rRNA was monitored as an internal control. The expression of sIL1 Ra was corrected for $28 S$ rRNA levels and the IL $1 R a / 28 S$ ratios were normalised to the maximal value observed in each experiment, which was set to $100 \%$. The results shown represent the mean (SEM) of data obtained with three samples from different donors (one normal adult femoral head, one normal paediatric vertebra, and one OA femoral head).

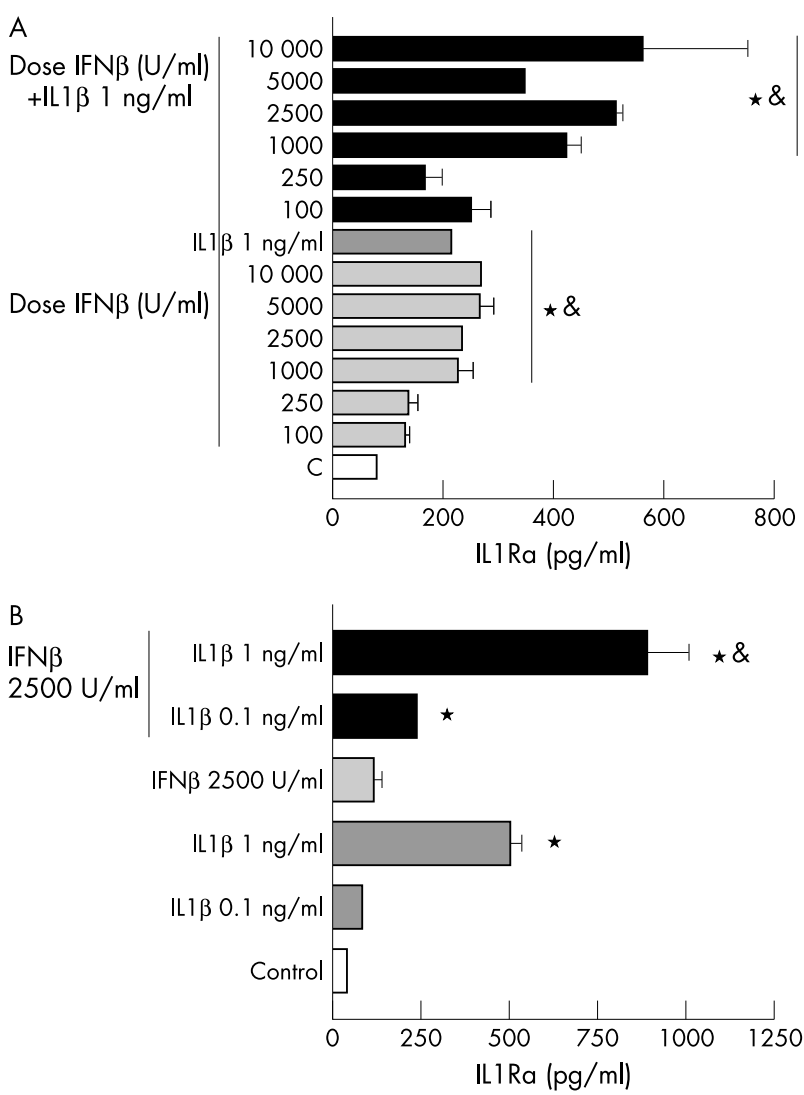

Figure 5 Dose dependent effects of IFN $\beta$ and IL $1 \beta$ on ILI Ra production in human synovial fibroblasts. (A) Human OA synovial fibroblasts (passage 4) were left unstimulated (control; white bars) or stimulated with indicated doses of IFN $\beta$ (grey bars; $250 \mathrm{U} / \mathrm{ml}$ corresponds to $1 \mathrm{ng} / \mathrm{ml}$ ), $1 \mathrm{ng} / \mathrm{ml}$ IL $1 \beta$ (dark grey bar), or the combination of $1 \mathrm{ng} / \mathrm{ml}$ ILI $\beta$ and indicated doses of IFN $\beta$ (black bars) for 72 hours. (B) Human OA synovial fibroblasts (passage 5) were left unstimulated (control; white bars) or stimulated with indicated doses of IL1 $\beta$ (dark grey bars), $2500 \mathrm{U} / \mathrm{ml}(10 \mathrm{ng} / \mathrm{ml})$ IFN $\beta$ (grey bar), or the combination of 2500 $\mathrm{U} / \mathrm{ml}(10 \mathrm{ng} / \mathrm{ml}$ ) IFN $\beta$ and indicated doses of IL $1 \beta$ (black bars) for 72 hours. IL1Ra concentrations in culture supernatants were measured by ELISA. Each bar represents the mean (SEM) of three determinations in a representative experiment. * $p<0.05$ as compared with control;

$\& p<0.05$ as compared with cells treated with the same dose of ILI $\beta$ alone.

In contrast with culture supernatants, cell lysates of primary human chondrocytes contained undetectable or low levels of ILIRa, even after stimulation with ILI $\beta$ and IFN $\beta$ (fig 3A). This observation suggests that primary articular chondrocytes produce essentially the secreted IL1Ra isoform. Similar results were obtained with cells from two different donors (normal adult femoral head and paediatric vertebra). Stimulated levels of ILIRa in cell lysates increased somewhat with passages in dedifferentiated chondrocytes (fig 3B). This observation was confirmed using cells from three different donors (three OA femoral head samples).

\section{Expression of sILIRa and icILIRal transcripts in human articular chondrocytes}

To further characterise the ILIRa isoforms expressed in articular chondrocytes in response to ILl $\beta$ and IFN $\beta$, we quantified the expression of sILlRa and icILlRal transcripts by real time RT-PCR using isoform-specific primers (tables 1 and 2$)$. ILl $\beta(1 \mathrm{ng} / \mathrm{ml})$ induced the expression of sILIRa mRNA in human chondrocytes, as previously reported. ${ }^{21}$ Expression of sILlRa mRNA tended to be further enhanced when ILl $\beta$ was combined with IFN $\beta(2500 \mathrm{U} / \mathrm{ml})$, although the difference in expression levels did not reach statistical 
Table 4 IL1Ra secretion by human synovial fibroblasts

\begin{tabular}{lll}
\hline Samples & Condition & ILIRa $(\%$ of maximum) \\
\hline OA $(n=7)$ & Control & $12.69(3.32)$ \\
& IFN $\beta$ & $30.99(7.60) \ddagger$ \\
& ILI $\beta$ & $45.01(5.14) \ddagger$ \\
RA $(n=3)$ & IFN $\beta$ and IL1 $\beta^{*}$ & $100(0) \ddagger \S$ \\
& Control & $4.55(4.55)$ \\
& IFN $\beta$ & $15.75(1.95)$ \\
& ILI $\beta$ & $46.02(9.65 \ddagger$ \\
& IFN $\beta$ and IL1 $\beta \dagger$ & $100(0) \ddagger \S$
\end{tabular}

*ILI Ra secretion in OA cells (passages 1 to 6 , seven different donors) stimulated with $2500 \mathrm{U} / \mathrm{ml} \mathrm{IFN} \beta$ and $1 \mathrm{ng} / \mathrm{ml} \mathrm{IL1} \beta$ ranged from 177.2 to $881.0 \mathrm{ng} / \mathrm{ml}$ (mean (SEM) 476.1 (90.5)); †ILIRa secretion in RA cells (passages 2-12, three different donors) stimulated with $2500 \mathrm{U} / \mathrm{ml}$ IFN $\beta$ and $1 \mathrm{ng} / \mathrm{ml} \mathrm{IL1} \beta$ ranged from 1126.7 to $1480.2 \mathrm{ng} / \mathrm{ml}$ (mean (SEM) 1327.6 (104.9)); $\ddagger p<0.05 v$ control; $\S p<0.001 v$ ILI $\beta$ or IFN $\beta$ alone.

significance (fig 4). The effects of ILl $\beta$ and IFN $\beta$ on ILIRa protein secretion, measured by ELISA (fig 2), were thus associated with increased sIL1Ra mRNA expression (fig 4). Expression of icILIRal mRNA was generally not detectable in these experiments (data not shown), which is consistent with the very small amounts of IL1Ra detected in cell lysates, confirming that human articular chondrocytes primarily produce sILIRa. ${ }^{21}$

\section{Production of ILIRa in response to IFN $\beta$ and IL $1 \beta$ in human synovial fibroblasts}

While IFN $\beta$ alone failed to modulate IL1Ra production in chondrocytes, it increased the secretion of IL1Ra by human synovial fibroblasts in a dose dependent manner (fig 5A). In addition, like in chondrocytes, IFN $\beta$ dose dependently enhanced the stimulatory effect of ILI $\beta$ on ILIRa production by synovial fibroblasts. A maximal effect of IFN $\beta$ was observed with $1000 \mathrm{U} / \mathrm{ml}$ (fig 5A). A similar dose dependency was observed with cells from four different donors (three OA and one RA samples). In fact, the relative ILIRa expression levels induced by IFN $\beta$, IL1 $\beta$, or the combination of the two cytokines were identical in OA and RA samples, although the absolute quantities of ILIRa produced were higher in RA than in OA synovial fibroblasts (table 4, figs 5 and 6). The stimulation of ILIRa production by ILI $\beta$, used either alone or

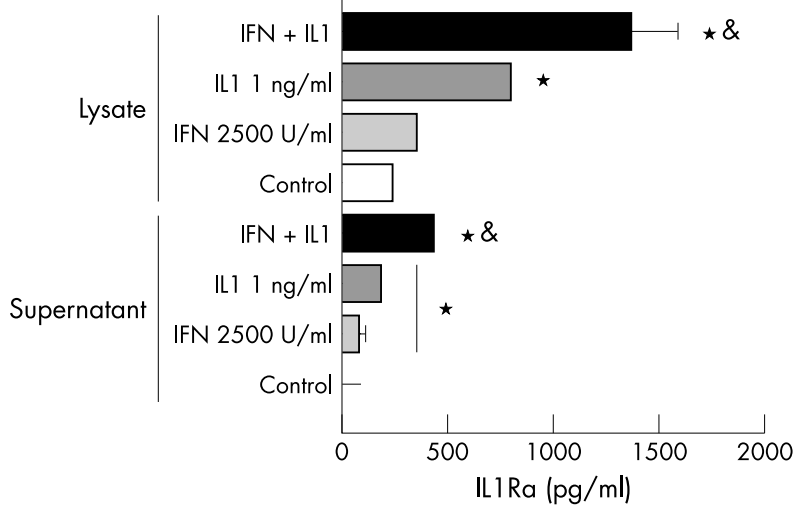

Figure 6 Effects of IFN $\beta$ and ILI $\beta$ on the production of secreted and intracellular IL1Ra in human synovial fibroblasts. Human RA synovial fibroblasts (passage 5) were left unstimulated (control; white bars) or stimulated with $2500 \mathrm{U} / \mathrm{ml}(10 \mathrm{ng} / \mathrm{ml}$ ) IFN $\beta$ (grey bars), $1 \mathrm{ng} / \mathrm{ml} \mathrm{IL1} \beta$ (dark grey bars), or the combination of $2500 \mathrm{U} / \mathrm{ml}(10 \mathrm{ng} / \mathrm{ml})$ IFN $\beta$ and $1 \mathrm{ng} / \mathrm{ml}$ IL1 $\beta$ (black bars) for 72 hours. ILIRa concentrations in culture supernatants and cell lysates were measured by ELISA. Each bar represents the mean (SEM) of three determinations in a representative experiment. ${ }^{*} p<0.05$ as compared with control; $\& p<0.05$ as compared with cells treated with ILI $\beta$ alone.
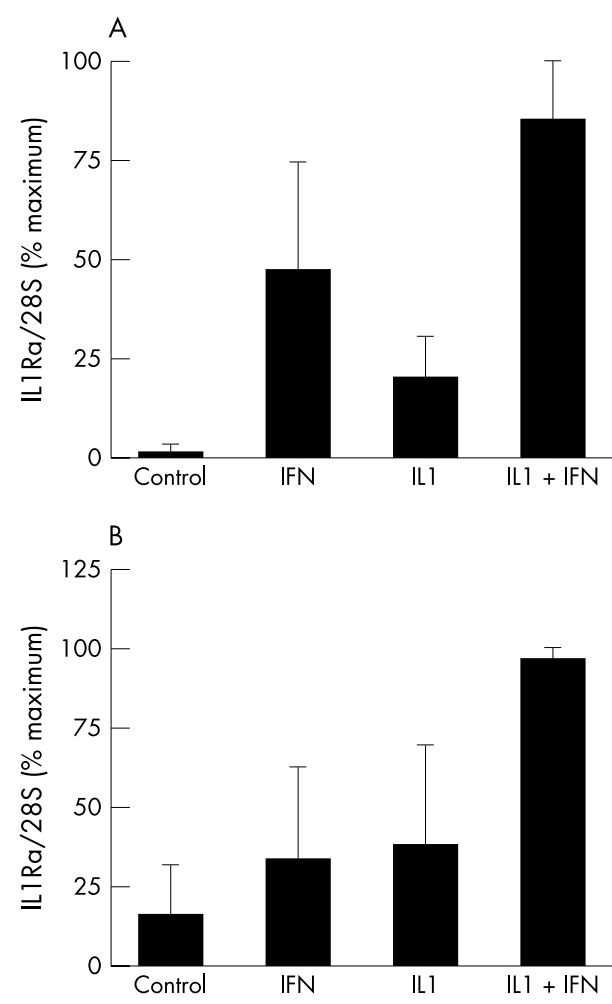

Figure 7 Effects of IFN $\beta$ and ILI $\beta$ on the expression of sILIRa and iclL1Ra1 mRNA in human synovial fibroblasts. Expression levels of mRNA encoding (A) sILIRa and (B) iclL1Ral were quantified by real time RT-PCR using total RNA from human synovial fibroblasts (passages 2-14). Cells were left unstimulated (control) or stimulated for 18 hours with $2500 \mathrm{U} / \mathrm{ml}(10 \mathrm{ng} / \mathrm{ml}$ ) IFN $\beta$ (IFN), $1 \mathrm{ng} / \mathrm{ml} \mathrm{IL1} \beta$ (IL1) or the combination of $2500 \mathrm{U} / \mathrm{ml}(10 \mathrm{ng} / \mathrm{ml})$ IFN $\beta$ and $1 \mathrm{ng} / \mathrm{ml}$ ILI $\beta$ (IL1 + IFN). The amount of $28 S$ rRNA was monitored as an internal control. The expression of sIL1Ra or iclL1Ral was corrected for 28S rRNA levels and the ILIRa/28S ratios were normalised to the maximal value observed in each experiment, which was set to $100 \%$. The results shown represent the mean (SEM) of data obtained with three samples from different donors (one OA and two RA samples).

in combination with IFN $\beta$, was also dose dependent (fig 5B). Again, similar relative expression levels were observed with cells from two different donors (one OA and one RA sample).

The effects of IFN $\beta$ and ILI $\beta$ on ILIRa secretion by synovial fibroblasts were time dependent and maximal after 72 hours of stimulation (data not shown). In synovial cell lysates, ILIRa levels were often detectable already in unstimulated cells and they increased in parallel with ILIRa secretion upon stimulation with IFN $\beta$ and ILl $\beta$ (fig 6). Similar data were obtained with synovial cells from three different donors (one OA and two RA samples).

\section{Expression of sIL1Ra and icIL1Ral transcripts in human synovial fibroblasts}

To further characterise the IL1Ra isoforms expressed in human synovial fibroblasts in response to ILI $\beta$ and IFN $\beta$, we quantified the expression of sILlRa and icILIRal transcripts by real time RT-PCR using isoform-specific primers (tables 1 and 2). IFN $\beta(2500 \mathrm{U} / \mathrm{ml})$ and $\operatorname{ILl} \beta$ ( $1 \mathrm{ng} / \mathrm{ml})$ alone induced the expression of sILIRa mRNA in human synovial fibroblasts and this effect tended to be further enhanced when both cytokines were added together, although the difference in expression levels did not reach statistical significance (fig 7A). Similarly, ILl $\beta$ and IFN $\beta$ increased icILlRal mRNA expression in human synovial fibroblasts (fig 7B). The effects of ILI $\beta$ and IFN $\beta$ on secreted and intracellular ILIRa production, measured by ELISA (figs 5 and 6), were thus 
paralleled by changes in steady state levels of sILIRa and icILIRal mRNA (fig 7).

\section{DISCUSSION}

In this study we described increased production of ILlRa in human joint cells treated with IFN $\beta$. IFN $\beta$ had been previously reported to increase ILIRa production in various cell types, and raised serum ILlRa levels are seen in patients with multiple sclerosis treated with IFN $\beta .^{12-14} 2223$ However, although IFN $\beta$ has been considered for the treatment of RA, the effects of IFN $\beta$ on the production of this antiinflammatory cytokine had, to our knowledge, never been investigated in joint cells.

We previously observed that human articular chondrocytes produce sILlRa when stimulated with ILl $\beta$, alone or in combination with IL6. ${ }^{21}$ A recent report described the biological effects of IFN $\beta$ in a human chondrosarcoma derived chondrocytic cell line, suggesting that chondrocytes are responsive to IFN $\beta .{ }^{15}$ We report that human chondrocytes indeed express mRNA encoding type I interferon receptors and that IFN $\beta$ modulates ILl $\beta$ induced ILIRa production in these cells. Although IFN $\beta$ displayed no stimulatory effect on its own, it markedly enhanced ILIRa secretion in response to ILI $\beta$. In addition, the results of our study confirm that human articular chondrocytes essentially express the sILIRa isoform. ${ }^{21}$

Synovial fibroblasts themselves produce low amounts of IFN $\beta$, as visualised by immunofluorescence on synovial specimens (Tak PP, personal communication). Large amounts of IFN $\beta$, however, appear to be produced by fibroblastic cells only upon exposure to viral and, to a lesser extent, non-viral pathogen associated molecules. ${ }^{24}$ Biological effects of IFN $\beta$ were previously seen in RA synovial fibroblasts and include inhibition of matrix metalloproteinase (MMP)-1, MMP-3, and prostaglandin $\mathrm{E}_{2}$ production. ${ }^{16} \mathrm{~A}$ potential effect of IFN $\beta$ on ILIRa production had not been investigated. We observed that IFN $\beta$ alone increases ILIRa secretion in synovial fibroblasts. In addition, IFN $\beta$ enhanced the stimulatory effect of ILI $\beta$ on ILIRa production. Synovial fibroblasts produced secreted and intracellular ILIRa and the expression of both sILlRa and icILlRal isoforms was increased in response to ILI $\beta$ and IFN $\beta$.

The exact biological functions of the different ILIRa isoforms are still not clear. ${ }^{725} 26$ The major role of sIL1Ra is to block the effects of ILl at the cell surface. The intracellular isoforms may be released from cells under some circumstances, but it has also been suggested that they perform important regulatory roles within cells. In a recent study, we observed that overexpression of either sIL1Ra or icILIRal similarly protected mice from collagen induced arthritis (CIA), blocking inflammation and joint damage. ${ }^{27}$ The significance of the observed increase in IL1Ra levels induced by IFN $\beta$ can be questioned given that a significant excess of IL1RA is necessary to block the effects of ILl. High amounts of ILl are needed to observe maximal catabolic effects in vitro. However, multiple evidence (see Chabaud et al, ${ }^{28}$ among others) indicates that even very low levels of catabolic cytokines, including ILl, at suboptimal concentrations, can synergistically induce large effects. In vivo, most probably, a cocktail of cytokines, each present in low amounts, induces proinflammatory and catabolic effects synergistically. It is then likely sufficient to block lower amounts of ILl to decrease synergisms in vivo. The increased production of both sILIRa and icILlRal isoforms seen in joint cells in response to IFN $\beta$ is thus potentially beneficial by preventing joint damage in inflammatory arthropathies such as RA. In this regard, treatment with IFN $\beta$ has been shown to limit the severity of CIA, decreasing, in particular, cartilage destruction. ${ }^{1}$ The mechanisms of this protection may be multiple.
However, a stimulatory effect on ILlRa synthesis might be particularly relevant given the likely central role of ILl in CIA. ${ }^{29}$

A phase I study with IFN $\beta$ in 12 patients with RA showed a significant clinical and immunohistological improvement: improved measures included swollen joint counts, as well as MMP-1 and tissue inhibitor of metalloproteinases (TIMP) expression. ${ }^{30}$ These effects of IFN $\beta$ could likewise be beneficial in other conditions characterised by cartilage degradation, including OA. ILl together with the MMP/ TIMP ratio are indeed thought to play an important part in this disease. ${ }^{2-4}$ The effects of IFN $\beta$ observed in the present study in OA chondrocytes and synoviocytes are thus interesting by indicating that not only these two major types of joint cells increase their synthesis of ILIRa in response to IFN $\beta$ but also that this response is conserved during OA. At this time, no treatment compellingly prevents cartilage degradation in OA. IFN $\beta$ has been shown to display multiple effects, including a decrease in the synthesis of ILl and MMPs, which might contribute to cartilage protection. ${ }^{1}$ This study, showing that IFN $\beta$ also increases ILIRa synthesis in human articular chondrocytes, further defines it as a molecule potentially available in treatment strategies for cartilage damaging diseases.

The plasma concentrations of IFN $\beta$ achieved in vivo during treatment by parenteral injections only range from 12 to $25 \mathrm{IU} / \mathrm{ml}$. The concentrations present in the direct synoviocyte or chondrocyte environment during treatment are unknown, but IFN $\beta$ decreases very rapidly from the plasma after an injection; a significant fraction of the molecules is probably directed towards sites of inflammation and bound to receptors. In any event, our results provide information on the possible benefits of delivering IFN $\beta$ by intra-articular injections or gene therapy.

In conclusion, human articular chondrocytes, as well as synovial fibroblasts, respond to IFN $\beta$, which increases their production of ILlRa. In chondrocytes, the effect of IFN $\beta$ was seen only when IFN $\beta$ was added in combination with ILl $\beta$, while in synovial fibroblasts, IFN $\beta$ alone dose dependently increased ILlRa production. These observations suggest that IFN $\beta$ may exert beneficial effects in cartilage damaging diseases, by increasing ILIRa production in joint cells.

\section{ACKNOWLEDGEMENTS}

This work was supported by grants from the Swiss National Science Foundation (No 3100-064123.00/1 to PAG; No 3200-054955.98 and 3231-05454.98 to CG).

\section{Authors' affiliations}

G Palmer, F Mezin, C Gabay, P-A Guerne, Division of Rheumatology, University Hospital, and Department of Pathology, University of Geneva School of Medicine, Geneva, Switzerland

C E Juge-Aubry, Division of Endocrinology and Diabetes, University Hospital, Geneva, Switzerland

C Plater-Zyberk, Elan Pharma, Esplanade Grand Siècle 2, 78009

Versailles, Cedex, France

\section{REFERENCES}

1 van Holten J, Plater-Zyberk C, Tak PP. Interferon- $\beta$ for treatment of rheumatoid arthritis? Arthritis Res 2002;4:346-52.

2 Martel-Pelletier J, Alaaeddine N, Pelletier JP. Cytokines and their role in the pathophysiology of osteoarthritis. Front Biosci 1999;4:D694-703.

3 Lotz M, Blanco FJ, von Kempis J, Dudler J, Maier R, Villiger PM, et al. Cytokine regulation of chondrocyte functions. J Rheumatol Suppl 1995;43:104-8.

4 Fernandes J, Tardif G, Martel-Pelletier J, Lascau-Coman V, Dupuis M,

Moldovan $F$, et al. In vivo transfer of interleukin-1 receptor antagonist gene in osteoarthritic rabbit knee joints: prevention of osteoarthritis progression. Am J Pathol 1999; 154:1159-69.

5 Dripps DJ, Brandhuber BJ, Thompson RC, Eisenberg SP. Interleukin-1 (IL-1) receptor antagonist binds to the $80-\mathrm{kDa}$ IL-1 receptor but does not initiate IL- 1 signal transduction. J Biol Chem 1991;266:10331-6. 
6 Granowitz EV, Clark BD, Mancilla J, Dinarello CA. Interleukin-1 recepto antagonist competitively inhibits the binding of interleukin-1 to the type II interleukin-1 receptor. J Biol Chem 1991;266:14147-50.

7 Arend WP, Malyak M, Guthridge CJ, Gabay C. Interleukin-1 receptor antagonist: role in biology. Annu Rev Immunol 1998;16:27-55.

8 Hannum CH, Wilcox CJ, Arend WP, Joslin FG, Dripps DJ, Heimdal PL, et al. Interleukin-1 receptor antagonist activity of a human interleukin-1 inhibitor. Nature 1990;343:336-40.

9 Haskill S, Martin G, Van Le L, Morris J, Peace A, Bigler CF, et al. cDNA cloning of an intracellular form of the human interleukin 1 receptor antagonist associated with epithelium. Proc Natl Acad Sci USA 1991:88:3681-5.

10 Muzio M, Polentarutti N, Sironi M, Poli G, De Gioia L, Introna M, et al. Cloning and characterization of a new isoform of the interleukin 1 receptor antagonist. J Exp Med 1995;182:623-8.

11 Malyak M, Guthridge JM, Hance KR, Dower SK, Freed JH, Arend WP. Characterization of a low molecular weight isoform of IL-1 receptor antagonist. J Immunol 1998;161:1997-2003.

12 Coclet-Ninin J, Dayer JM, Burger D. Interferon-beta not only inhibits interleukin-1 beta and tumor necrosis factor-alpha but stimulates interleukin-1 receptor antagonist production in human peripheral blood mononuclear cells. Eur Cytokine Netw 1997;8:345-9.

13 Sciacca FL, Canal N, Grimaldi LM. Induction of IL- 1 receptor antagonist by interferon beta: implication for the treatment of multiple sclerosis. J Neurovirol 2000;6(suppl 2):S33-7.

14 Liu JS, Amaral TD, Brosnan CF, Lee SC. IFNs are critical regulators of IL-1 receptor antagonist and IL-1 expression in human microglia. J Immunol 1998; 161:1989-96.

15 Hattori T, Kubota S, Yutani Y, Fujisawa T, Nakanishi T, Takahashi K, et al. Change in cellular localization of a rheumatoid arthritis-related antigen (RAA47) with downregulation upon stimulation by inflammatory cytokines in chondrocytes. J Cell Physiol 2001;186:268-81.

16 Smeets TJ, Dayer JM, Kraan MC, Versendaal J, Chicheportiche R, Breedveld FC, et al. The effects of interferon-beta treatment of synovial inflammation and expression of metalloproteinases in patients with rheumatoid arthritis. Arthritis Rheum 2000;43:270-4.

17 Lotz M, Clark-Lewis I, Ganu V. HIV-1 transactivator protein Tat induces proliferation and TGF beta expression in human articular chondrocytes. J Cell Biol 1994; 124:365-71.

18 Klareskog L, Forsum U, Malmnas Tjernlund UK, Kabelitz D, Wigren A. Appearance of anti-HLA-DR-reactive cells in normal and rheumatoid synovial tissue. Scand J Immunol 1981;14:183-92.
19 Gabay C, Smith MF, Eidlen D, Arend WP. Interleukin 1 receptor antagonist (IL-1Ra) is an acute-phase protein. J Clin Invest 1997;99:2930-40.

20 Oritani K, Kincade PW, Zhang C, Tomiyama Y, Matsuzawa Y. Type I interferons and limitin: a comparison of structures, receptors, and functions. Cytokine Growth Factor Rev 2001;12:337-48.

21 Palmer G, Guerne PA, Mezin F, Maret M, Guicheux J, Goldring MB, et al. Production of interleukin-1 receptor antagonist by human articular chondrocytes. Arthritis Res 2002;4:226-31.

22 Nicoletti F, Patti F, DiMarco R, Zaccone P, Nicoletti A, Meroni P, et al. Circulating serum levels of IL-1 ra in patients with relapsing remitting multiple sclerosis are normal during remission phases but significantly increased either during exacerbations or in response to IFN-beta treatment. Cytokine 1996;8:395-400.

23 Perini P, Tiberio M, Sivieri S, Facchinetti A, Biasi G, Gallo P. Interleukin-1 receptor antagonist, soluble tumor necrosis factor-alpha receptor type I and II, and soluble E-selectin serum levels in multiple sclerosis patients receiving weekly intramuscular injections of interferon-betala. Eur Cytokine Netw 2000;11:81-6.

24 Taniguchi T, Takaoka A. A weak signal for strong responses: interferon-alpha/beta revisited. Nat Rev Mol Cell Biol $2001 ; 2: 378-86$.

25 Muzio M, Polentarutti N, Facchetti F, Peri G, Doni A, Sironi M, et al. Characterization of type II intracellular IL-1 receptor antagonist (IL-1 ra3): a depot IL-1 ra. Eur J Immunol 1999;29:781-8.

26 Watson JM, Lofquist AK, Rinehart CA, Olsen JC, Makarov SS, Kaufman DG, et al. The intracellular IL-1 receptor antagonist alters IL-1-inducible gene expression without blocking exogenous signaling by IL-1 beta. J Immunol 1995; 155:4467-75.

27 Palmer G, Talabot-Ayer D, Szalay-Quinodoz I, Maret M, Arend WP, Gabay C. Mice transgenic for intracellular interleukin-1 receptor antagonist type 1 are protected from collagen-induced arthritis. Eur J Immunol 2003;33:434-40.

28 Chabaud M, Page G, Miossec P. Enhancing effect of IL-1, IL-17, and TNFalpha on macrophage inflammatory protein-3alpha production in rheumatoid arthritis: regulation by soluble receptors and Th2 cytokines. J Immunol 2001;167:6015-20.

29 van de Loo FA, van den Berg WB. Gene therapy for rheumatoid arthritis. Lessons from animal models, including studies on interleukin-4, interleukin-10, and interleukin-1 receptor antagonist as potential disease modulators. Rheum Dis Clin North Am 2002;28:127-49.

30 Tak PP, Hart BA, Kraan MC, Jonker M, Smeets TJ, Breedveld FC. The effects of interferon beta treatment on arthritis. Rheumatology (Oxford) 1999;38:362-9. 